\title{
Refugee Flows and Humanitarian Intervention: Problems of Selectivity and Politicization
}

\author{
Michael Barutciski
}

\begin{abstract}
This article examines some of the problems related to humanitarian intervention in situations of mass displacement. Comparisons between the significant resources spent on the conflict in the former Yugoslavia and the lesser resources spent on other less-publicized conflicts are used to illustrate the basic unfairness regarding the selective nature of international interventions. Examples of local manipulation resulting from the politicization of the intervention in Bosnia-Herzegovina are used to further illustrate the complications that may arise when intervention replaces asylum in response to humanitarian tragedies.

\section{Précis}

Cet article examine quelques problèmes liés aux interventions humanitaires dans des situations de déplacements massifs. Les ressources considérables qui ont été consacrées à l'intervention dans l'ancienne Yougoslavie sont comparées aux ressources limitées qui sont réservées pour d'autres conflits moins médiatisés. Des exemples de manipulations de la part des belligérants en Bosnie-Herzégovine sont également présentés pour illustrer les complications qui peuvent se développer quand des solutions interventionistes sont proposées pour remplacer l'asile en cas de crise humanitaire.
\end{abstract}

This article focuses on two issues that have characterized humanitarian intervention in recent years: selectivity and politicization. Although problems related to selectivity and politicization

Michael Barutciski is a legal consultant to the Refugee Law Research Unit, Centre for Refugee Studies. are inherent to much of the United Nations' activities, the extent to which they have manifested themselves in recent years is troublesome. The example of the UN involvement in BosniaHerzegovina is used to demonstrate the basic unfairness in the way limited resources are spent world wide and the complications that can arise when the international community attempts to lead an impartial humanitarian operation in a region torn by internal armed conflict.

It is important to note that recent examples of humanitarian intervention have occurred in a period when states are coordinating their efforts in order to close their borders to potential asylum seekers. Along with facilitating the containment of refugee flows, humanitarian intervention and the accompanying principal relief aid role reserved for the Office of the UN High Commissioner for Refugees can be advantageous for many states in that it relegates refugee protection to the weaker aspect of the 1951 Refugee Convention's protection regime: institutional emergency assistance by UNHCR. This form of assistance is less threatening to states since it avoids the legal obligations associated with the granting of asylum. The ad hoc and discretionary nature of UNHCR's emergency assistance are particularly attractive in a period characterized by diminishing commitments to asylum and a new emphasis on addressing the "root causes" of refugee flows.

\section{Selectivity of Interventions in Cases of Refugee Outflow}

There are cases when the violence and humanitarian crisis surrounding displacement achieve so much visibility that the international community is forced to intervene militarily. The mass displacement of Kurds in Iraq following the Gulf War was such a case. With the brutal application of non-admission measures at the Turkish border, the international news media's coverage of the Kurds' plight compelled Western states to provide a form of in-country protection that was designed to avoid further regional destabilization. The fact that the government of Iraq had just been defeated militarily made it possible for the West to bypass strict state sovereignty in order to protect the Kurds. These victims of displacement thus benefited from the establishment of a "safe haven" which was intended to eliminate their reasons for fleeing. It is important to note that the UN Security Council declared that the threat to international peace and security resulted from the regionally destabilizing refugee flow and not the human rights violations which prompted victims to flee. ${ }^{1}$ Several months after the slaughter and mass displacement had begun in Rwanda during the Spring of 1994, the Security Council's declaration that the magnitude of the humanitarian crisis constituted a threat to peace and security in the region allowed a military intervention by France in order to create a "safe haven" in the southwestern part of the country. ${ }^{2}$ Similarly, the Security Council's declaration that the situation in Haiti constituted a threat to peace and security in the region was followed by an authorization to have a multinational military force led by the United States intervene while asylum seekers were effectively prevented from escaping to the US. ${ }^{3}$

Since these interventions were all intimately linked to refugee flows, it may seem understandable that UNHCR was given an important (although varying) role in each of them. However, it should be remembered that UNHCR's original role regarding 
international refugee protection did not comprise an interventionist aspect since the agency was supposed to defend the asylum conditions of refugees in host states. The interest in humanitarian intervention following the end of the Cold War has changed this traditional approach to refugee protection. Most importantly, the discretionary nature of UNHCR's in-country emergency assistance has always resulted in the differentiated treatment of the world's refugees. The practice of earmarking contributions to UNHCR has led to situations where certain humanitarian operations that attract sufficient attention have been well funded while others go unnoticed and remain short of funds. ${ }^{4}$ Whether the attention is accorded because of international sympathy generated by the news media or more direct state interests, the selectivity inherent to earmarked voluntary contributions assures $\mathrm{UNH}$ $C R$ 's dependence and vulnerability in relation to the financing states.

In the present context of limited and selective interventions, it is not surprising that the former Yugoslavia's geographic location makes it pertinent to the interests of the states that control UNHCR. Reports of widespread human rights violations in Bosnia-Herzegovina have also assured that the victimized civilian populations remain the object of considerable international sympathy. Consequently, UNHCR has received substantial funding for this particular intervention. In fact, expenditures in the former Yugoslavia have been greatly disproportionate in comparison to expenditures for the entire African continent. In 1992, the funds allocated to the operation in the former Yugoslavia (US\$296,518,600) were almost as much as the funds spent on all the programs for the African continent (US\$298, $169,900)$. In 1993, expenditures in the former Yugoslavia (US\$532,640,000) were greater than expenditures for Africa (US\$325,141,000), and East Asia and Oceania (US\$144,397,600) combined. ${ }^{5}$ Unfairness resulting from the selectivity of UNHCR's emergency assistance has meant that once again
European human rights victims receive more attention than a much larger group of African victims. At the end of 1993, 5,825,000 refugees and asylum seekers were in need of protection or assistance in Africa. A further $16,890,000$ individuals were displaced within their African states. The former Yugoslavia, on the other hand, had generated approximately $1,319,650$ refugees and 1,650,000 internally displaced civilians. ${ }^{6}$ The UN High Commissioner for Refugees has quite appropriately warned that the legitimacy of UN operations suffers as a result of this kind of differentiated treatment:

I must express my strong preoccupation at a refugee situation which is draining precious financial and human resources desperately needed in other parts of the world, mainly Africa and Asia. It would be remiss of me not to point out the crying needs in poorer parts of the world which are being overshadowed by the refugees from ex-Yugoslavia. ${ }^{7}$

Non-UN agencies such as the International Committee of the Red Cross provide a good example of a more balanced approach to various global operational requirements: in 1992, ICRC activities in Africa were evaluated at $393,600,000 \mathrm{CHF}$ while activities in Europe (former Yugoslavia and ex-Soviet Union) were evaluated at $120,600,000 \mathrm{CHF}^{8}$ It was only after several years of operations in the former Yugoslavia that UNHCR established a more reasonable balance in relation to the limited resources available worldwide. In 1994, UNHCR expenditures in the former Yugoslavia amounted to US\$226,524,800 while its expenditures in Africa amounted to US\$506,090,900. ${ }^{9}$

The recent interest in promoting humanitarian interventions and the accompanying principal humanitarian aid role reserved for UNHCR will likely result in greater unfairness due to the selectivity of these operations. As refugees around the world increasingly lose the ability to seek asylum autonomously, the ad hoc and discretionary nature of institutional re- sponses to displacement increase the risk that groups of coerced migrants will be left abandoned by the international community in situations where both asylum and intervention are not forthcoming. This tendency can only be avoided in the unlikely event that states increase their commitment to humanitarian interventions.

It is also unlikely that the selective concerns and interests of states can be reliably balanced by public pressure which will encourage interventions that are motivated by truly "humanitarian" concerns in remote parts of the world. While public opinion can react strongly when informed of humanitarian tragedies, well-informed and unbiased public with charitable intentions are not easy to find. Technological improvements in communication systems do not assure an evenhanded and comprehensive flow of information.

The influence of the international news media and the distorted sense of public awareness it has created can be illustrated by comparing statistics on recent international conflicts. The estimated total number of war-related deaths in Bosnia-Herzegovina is identical to the estimate regarding the conflict in Tajikistan $(20,000-50,000) .{ }^{10} \mathrm{It}$ is also comparable to various lesspublicized conflicts around the world: Algeria since 1992 (10,000-25,000), Sri Lanka since 1983 (>27,000), Liberia $(20,000)$, Peru since $1981(>28,000)$, Philippines since $1986(21,000-25,000)$. Even the prolonged conflict in Guatemala has produced comparable statistics on total deaths $(<46,300)$. Yet these other conflicts have received limited or minimal international attention, while conflicts with considerably more casualties (e.g. Sudan, Angola) are unable to attract significant international concern. It should be noted that journalists and politicians regularly used inflated figures for total warrelated deaths in Bosnia-Herzegovina (200,000-250,000). Statistics for 1994 are particularly revealing: although the year saw more war-related deaths in Afghanistan (4,000-10,000), Yemen $(1,500-7,000)$ and Turkey $(>3,000)$, it is the relentless image of suffering in 
Bosnia-Herzegovina ( $>1,500$ deaths) that characterized much of the year's journalistic coverage of international conflict.

The portrayal of suffering in BosniaHerzegovina remains accurate particularly to the extent that it depicts the human rights violations that were associated with the brutal program of orchestrated expulsions and deportations. Indeed, the statistics cited above regarding displacement in the former Yugoslavia indicate the extent to which ethnic cleansing has been practiced over the last few years. For example, in northern Bosnia-Herzegovina approximately 469,549 Muslims and Croats have been driven from territory controlled by the Serbs (out of a population of Muslims and Croats that included 536,549 before the war). In eastern Bosnia and southern Herzegovina, approximately 297,641 Muslims and Croats have been forced to flee their homes (there were 301,641 Muslims and Croats before the war). ${ }^{11}$

Yet mass displacement on more distant continents unfortunately has not received a proportionate amount of media coverage. ${ }^{12}$ Considerable populations of internally displaced persons are found in Sudan $(4,000,000)$, Angola $(2,000,000)$, Afghanistan $(1,000,000)$ Liberia $(1,100,000)$, Sri Lanka $(525,000)$, Turkey $(2,000,000)$ and Peru $(600,000)$. The number of refugees who have fled their war-affected regions is equally staggering: Afghanistan $(2,835,000)$, Liberia $(784,000)$ and Sudan $(510,000)$ are but some of the examples. Since many of the lesser known conflicts barely get any coverage by the international news media, Western government leaders have not had to react to public outrage regarding these humanitarian tragedies as they have been doing in relation to Bosnia-Herzegovina since 1992.

\section{Politicization of Interventions within Refugee Producing Countries}

While selectivity can result in certain humanitarian tragedies being ignored, politicization continues to complicate those tragedies that manage to attract a

forceful international response. Indeed, relief aid delivered in the midst of an internal armed conflict can often be perceived as a political gesture. It should come as no surprise that it may be contested by enemies of the beneficiaries: "Increasingly, the UNHCR and aid agencies must operate in the midst of ongoing conflicts where even the most humanitarian activities are perceived by one or even all parties as a factor affecting the outcome of the confrontation." 13 This is why recent examples of intervention have been challenged by local belligerents who want to prevent international aid from reaching their enemies. It is often difficult for external actors to maintain the fiction of impartiality in these situations of intervention.

The UN involvement in BosniaHerzegovina further highlights the

\section{Perhaps the most outrageous attempts to influence international public opinion involved orchestrated massacres of friendly civilians who were sacrificed in order to blame the opposing side.}

cruel consequences of the politicization of interventions in that it has been confronted with numerous incidents which involve sacrificing civilian populations for political goals. Early in the conflict, UNPROFOR commanders had remarked that some of the actors were intentionally trying to internationalize the conflict in order to obtain a direct military intervention from which they expected to benefit. ${ }^{14}$ In relation to this effort to internationalize the conflict, UNPROFOR and UNHCR officials have correctly noted that the "CNN front" played an important role during the war. ${ }^{15}$ The international news media was used in order to generate public sympathy for some of the actors in the conflict. Although using the media to influence events is not necessarily objectionable, it can become problematic when genuinely objective information is replaced by propaganda emanating from one side in a civil war.

As reported by the UN Secretary General on several occasions, military provocations which resulted in dispro- portionate responses were a frequent tactic throughout the war. In fact, the actual siege of Sarajevo only began after Yugoslav Army (JNA) barracks in the city were blockaded. When a supposedly negotiated evacuation of one of these barracks was interrupted by an ambush in which several JNA officers were shot dead and 200 JNA soldiers were taken prisoner, the canons positioned around the city were used to retaliate and begin the long campaign of terror which was intended to subdue the local population. ${ }^{17}$ The $\mathrm{CNN}$ effect and the international public outrage resulting from artillery shells exploding in an urban centre proved to be too attractive to the city's political leaders who had promised before the outbreak of hostilities that JNA barracks would not be blockaded as they were in Croatia and Slovenia. ${ }^{18}$
The bombardments of Bosnia-Herzegovina's capital city that followed assured that television teams could broadcast startling war images around the world.

Perhaps the most outrageous attempts to influence international public opinion involved orchestrated massacres of friendly civilians who were sacrificed in order to blame the opposing side. These incidents are particularly troublesome because they appear to have been effective in achieving the desired result: mobilizing public opinion into pressuring governments to take action against one of the parties to the conflict.

One of the most publicized events occurred in May 1992 when two mortar shells killed seventeen people who were waiting outside a bakery located in a Muslim-controlled part of Sarajevo:

The pressure for some form of action to stop the fighting in $\mathrm{BiH}$ was growing among the international public, not just in the West but in Islamic countries as well. One of the turning 
points was the shelling of a bread queue in Sarajevo in the middle of May. The resulting carnage was recorded on possibly the most nauseating television footage of the war. In London at the time, I observed how entire news rooms stopped what they were doing and stared in deep shock at the pictures coming over the satellite feed ... [T] his war has confirmed that the influence of print or radio journalism is negligible when compared with the impact that a few minutes of video can have. The Serb forces around Sarajevo denied more vigorously than usual that they were responsible for the outrage. Instead, they insisted that Bosnian government forces had slaughtered their own people precisely in order to generate the effect which the incident provoked around the world. ${ }^{19}$

While the Serbs were effectively blamed by the international news media for the attack, information was eventually revealed indicating that the Muslims had organized the massacre in order to attribute responsibility to the Serbs. ${ }^{20}$ Three days after the incident, the UN Security Council imposed sanctions against Yugoslavia (Serbia and Montenegro). There are also serious allegations that the Muslims were responsible for the Markale market massacre in Sarajevo in February 1994 that was attributed to the Serbs and led to a NATO ultimatum. ${ }^{21}$ This, of course, does not exculpate the Serbs (or other belligerents) who deliberately and openly bombarded civilian targets: for example, when NATO aircraft bombarded two Serb ammunition depots on May 25, 1995, the Serbs retaliated with their canons and killed seventy-one civilians in Tuzla. ${ }^{22}$ It does, however, indicate the complexities involved in having an international news media using its influence to openly encourage armed intervention in internal conflicts where civilians are being sacrificed by all sides. ${ }^{23}$

It should not be forgotten that an UNPROFOR commander could not complete his mandate because of death threats he received after trying to denounce these types of manipulation by the warring parties. ${ }^{24}$ The silence of the media regarding this manipulation of public opinion is particularly noteworthy if one considers that it was impossible to travel in the region without hearing rumours from UN personnel concerning massacres staged for television. Whether one considers the examples of snipers shooting at their own civilians in downtown Sarajevo ${ }^{25}$ or bombardments of the Sarajevo airport staged by the city's authorities, ${ }^{26}$ it should be understood that forming an accurate and nuanced picture of a distant conflict is hard to do from journalistic sources.

The fact that there have also been a considerable number of Serb victims in Bosnia-Herzegovina is striking if we consider that until the summer of 1995, the Muslims (and occasionally the Croats) were generally presented by the international news media as the only victims of ethnic cleansing. ${ }^{27}$ This perception persisted despite the fact that since mid-1993 most of the offensives in Bosnia-Herzegovina had been mounted by the Muslim forces (who, according to some American politicians, did not even have the weapons to defend themselves). ${ }^{28}$ Even if the Serbs were not able to militarily defeat the Muslim forces in certain key areas (Sarajevo, Bihac, Tuzla, Gorazde, Brcko) it is the Serb terror inflicted on besieged civilian populations that caught the attention of the international community. The ensuing journalistic encouragement for a military solution was so effective that the public debate in the US focused on lifting the UN arms embargo imposed on the former Yugoslavia. Although the embargo was not being respected by several UN member states and the Muslims were obtaining impressive quantities of armaments, ${ }^{29}$ the proposal circulating in journalistic and academic circles included a partial lifting of the embargo that would benefit the warring party that was generally perceived as the main victim. Eventually, American politicians were no longer hiding that they wanted to openly finance and arm the Muslims. ${ }^{30}$ The manipulation and international encouragement for a military solution to the conflict in Bosnia-Herzegovina reached a point where the emboldened Muslim forces decided it was not in their interest to allow the complete deployment of a more robust $\mathrm{UN}$ force (Rapid Reaction Force) that was supposed to protect their own civilian populations. ${ }^{31}$

It is useful to keep in mind that internal armed conflicts are rarely less complicated than the one in BosniaHerzegovina. In these highly politicized scenarios within countries of origin, affluent states are financing a supposedly "non-political" UNHCR ${ }^{32}$ so that it may engage in interventionist activities. Supported by UN military personnel with vaguely defined humanitarian roles, refugee protection is consequently reduced to emergency relief in war zones where manipulations and discredit can often be expected. In a sense, refugee law's contribution to international law is replaced by protection concerns that are part of humanitarian law. Yet for most victims of displacement, even the forceful interventions remain illusory in a system characterized by selective concern. The many problems associated with humanitarian intervention suggest that its use in relation to refugee outflows cannot be a reliable protection alternative to asylum.

\section{Notes}

1. Resolution 688 (April 5, 1991).

2. Resolution 929 (June 22, 1994).

3. Resolution 940 (July 31, 1994).

4. “Contributions can be earmarked for particular countries. As a result, donations for a cause such as repatriation in Cambodia, where the suffering under the Pol Pot regime touched a sympathetic chord around the world, ends up being oversubscribed. And repatriation in Mozambique, where a long-fought war is winding down in obscurity, does not raise enough money." John Darnton, "UN Faces Refugee Crisis that Never Ends," The New York Times, August 8, 1994, p. A6.

5. UNHCR, The State of the World's Refugees, New York: Penguin Books, 1993, p. 176 and UN Economic and Social Council, Report of the United Nations High Commissioner for Refugees, UN Doc. E/1994/41, May 6, 1994, p. 44.

6. See US Committee for Refugees, World Refugee Survey 1994, pp. 40-42.

(C) Michael Barutciski, 1996. This open-access work is licensed under a Creative Commons Attribution-NonCommercial 4.0 International License, which permits use, reproduction and distribution in any medium for non-commercial purposes, provided the original author(s) are credited and the original publication in Refuge: Canada's Journal on Refugees is cited. 
7. Sadako Ogata, Statement to the International Meeting on Humanitarian Aid for Victims of the Conflict in the Former Yugoslavia, Geneva, July 29, 1992, p. 5.

8. See International Committee of the Red Cross, Annual Report 1992, Geneva: ICRC Publications, 1993, p. 189.

9. UN Economic and Social Council, Report of the United Nations High Commissioner for Refugees, UN Doc. E/1995/52 (April 25, 1995), p. 44.

10. The following statistics on war-related deaths (up to and including 1994) are from the prestigious Stockholm International Peace Research Institute, SIPRI Yearbook 1995, London: Oxford University Press, 1995, pp. 26-33.

11. Statistics on displacement are from UNHCR, Information Notes on former Yugoslavia, no. 8/95, August 1995, p. 9.

12. The following statistics on displacement are from US Committee for Refugees, World Refugee Survey 1995, p. 44.

13. Gil Loescher, Beyond Charity: International Cooperation and the Global Refugee Crisis, New York: Oxford University Press, 1993, p. 28.

14. See generally Philippe Morillon, Croire et oser: Chroniques de Sarajevo, Paris: Éditions Grasset, 1993 and Lewis MacKenzie, Peacekeeper-The Road to Sarajevo, Vancouver: Douglas \& McIntyre, 1993.

15. Ibid. Also see Karin Landgren, "Safety Zones and International Protection: A Dark Grey Area," 7 International Journal of Refugee Law 436 (1995).

16. Report of the Secretary-General Pursuant to Security Council Resolution 900 (1994), UN Doc. S/1994/291 (March 11, 1994) and Report of the Secretary-General Pursuant to Security Council Resolution 982 (1995) and 987 (1995), UN Doc. S/1995/444 (May 30, 1995).

17. See Morillon, pp. 40-41 and MacKenzie, pp. 164-77.

18. "[President Izetbegovic] saw as the only alternative a repetition of the strategy that had earlier yielded results in both Slovenia and Croatia. He was, of course, aware that the result would be costly in terms of human lives, but that seemed to him an acceptable price to pay for sovereignty." Mihailo Crnobrnja, The Yugoslav Drama, Montreal: McGill-Queen's Press, 1994, p. 179.

19. Misha Glenny, The Fall of Yugoslavia, New York: Penguin, 1994, p. 210.

20. The UNPROFOR report regarding the massacre remains inaccessible to the public. However, its contents can be deduced from the diary of the highest ranking officer in Sarajevo at the time:
Disaster in Sarajevo. People lined up for bread were attacked, and at least seventeen killed. Presidency claims it was a Serb mortar attack, Serbs claim it was a setup using explosives. Our people tell us there were a number of things that didn't fit. The street had been blocked off just before the incident. Once the crowd was let in and had lined up, the media appeared but kept their distance. The attack took place, and the media were immediately on the scene. (Lewis MacKenzie, PeacekeeperThe Road to Sarajevo, Vancouver: Douglas \& McIntyre, 1993, p. 194. See also Daniel Vernet \& Jean-Marc Gonin, Le rêve sacrifié: Chroniques des guerres yougoslaves, Paris: Éditions Odile Jacob, 1994, pp. 106-7.)

21. David Binder, "Anatomy of a Massacre," Foreign Policy, no. 97, Winter 1994-1995, pp. 70-78.

22. UNHCR, Information Notes on former $Y u$ goslavia, no. 6/95, June 1995, p. i and UN Peace Forces News, no. 19, June 1995, p. 15.

23. Western journalists generally did not present a nuanced interpretation of the conflict. Some of the journalists who presented a Manichean view of the conflict have admitted that they were trying to influence events and help the Muslims by mobilizing public opinion). See, for example, Roy Gutman, A Witness to Genocide, New York: Macmillan, 1993, p. xii and the interview of Roy Gutman (Pulitzer Prize winner in 1993) in the American Journalism Review, July 1993.

24. General MacKenzie had to leave BosniaHerzegovina before the expiration of his mandate largely because of the death threats against himself and his assistants. The following excerpt of a message sent to General Nambiar (UNPROFOR Commander in Chief) summarizes the Muslim strategy:

You are aware of the desires of the Presidency to achieve international intervention in order to regain their country and capital. They are in fact perpetuating the current conflict, while the Serbs are showing considerable restraint (I can only speak for Sarajevo). Obviously, the Presidency does not like to hear me describe the facts as I know them, as this weakens their case with the international media. So far I have not gone public ... I can live with all the above [seven death threats]; after all I am a soldier; however, over the past few days, some of my personnel have been targeted due to their association with me ... This I cannot tolerate, as I am putting my personnel in needless danger. (MacKenzie, pp. 294-95.)

25. "French peacekeeping troops in the United Nations unit trying to curtail Bosnian Serb sniping at civilians in Sara- jevo have concluded that until mid-June [1995] some gunfire also came from Government soldiers deliberately shooting at their own civilians-French officers who conducted the investigation adamantly defend their findings ... One benefit of not making the matter official-thereby risking that it would become public-is to avoid a dispute between the Bosnian Government and the United Nations when the role and even the future of peacekeeping here are under intense review. (Mike O'Conner, "Investigation Concludes Bosnian Government Snipers Shot at Civilians," The New York Times, August 1, 1995, p. A6.)

26. "Some of the city's suffering has actually been imposed on it by actions of the Sarajevo government... Government soldiers, for example, have shelled the Sarajevo airport, the city's primary lifeline for relief supplies. The press and some governments, including that of the United States, usually attribute all such fire to the Serbs, but no seasoned observer in Sarajevo doubts for a moment that Muslim forces have found it in their interest to shell friendly targets. In this case, the shelling usually closes the airport for a time, driving up the price of black-market goods that enter the city via routes controlled by Bosnian army commanders and government officials. Similarly, during the winter of 1993-94, the municipal government helped deny water to the city's population. An American foundation had implemented an innovative scheme to pump water into the city's empty lines, only to be denied permission by the government for health reasons. The denial had less to do with water purity that with the opposition of some of Sarajevo officials who were reselling U.N. fuel donated to help distribute water. And, of course, the sight of Sarajevans lining up at water distribution points, sometimes under mortar and sniper fire, was a poignant image." Charles G. Boyd, "Making Peace with the Guilty: The Truth about Bosnia," Foreign Affairs, vol. 74, no. 5, September-October 1995 , p. 28.

27. The fate of Serb civilians in Sarajevo and elsewhere in Bosnia-Herzegovina has not received much sympathy from journalists or public opinion despite the fact that UNHCR had warned several months into the conflict that the dozens of thousands of inhabitants fleeing Sarajevo were mostly Serbs. In fact, the international news media has rarely considered the forced displacement of Serbs. Yet UN documents reveal that a significant portion of the displacement victims are of

Continued on page 22/Refugee Flows 